\title{
Purchase Behaviour of Women Grocery Consumers in Bangalore City
}

${ }^{*}$ Mrs. B. Menaka

** Dr. R. Ganapathi

Effulgence

Vol. 11 No. 1

January - June, 2013

Rukmini Devi Institute of Advanced Studies

E-mail : effulgence@rdias.ac.in, Website : www.rdias.ac.in

http:/ / effulgence.rdias.ac.in/user/default.aspX

A bstract

https://dx.doi.org/10.33601/effulgence.rdias/v11/i1/2013/23-39

Consumers decide the development of all businesses. In olden days much importance was not given to theattitudes and desires of consumers. The business peoplestated that their business was based on the knowledge and availability of funds. But now thesituation haschanged. Businessin all sectorsisconsumer oriented. Even beforecommencing businessitsed the business people try to know the desire, attitudes and behaviour of the consumers. This will enable them to supply the materialsat their convenienceto thesati faction of theconsumers. G roceriesarethei mportant dometic productswithout which it is very difficult to survive. Theseare considered as fast moving consumer goods. Many traders are involved in grocery business. Though they tried a lot to increase the potential customers but due to heavy competition many traders who areinvolved in thisbusinessarein a position to d osethebusiness. On many occasionsthey facecontinuouslossin their business. Bangal orecity in India experienced abnormal industrial development in thelast two decades. W ell known for Softwareindustry, Bangaloreisfamiliar for its development and incometo the government by way of foreign exchange Further most of theemployees in softwareand other industries prefer sophisticated lifeand usegroceries of high cost. So a number of grocery departmental storesand shopping compl exesareoperated in Bangalorecity.

Key W ords: PurchaseBehavi our, W omen G rocery, C onsumers, R etailing.

\section{INTRODUCTION}

$\mathrm{R}$ etailing occupies a predominant position in the economics of all modern societies. The retail sector is changing at an ever increasing pace and this is leading to greater competitor activity. This activity leads to the need to improve the way companies approach retail marketing. In the retail environment, it is often stated, the only constant is change and it is certainly true that the pace of development within retailing appears to be accelerating. At the close of the twentieth century, one is witnessing the emergence of new forms of retailing, in part in response to the demand from increasingly sophisticated consumers. The market is becoming more segmented with retail formats focusing on the needs of particular consumer groups.

Once it was the manufacturers' brands that were all important. The 1990s saw the power of the retailer brands challenging the position of the suppliers. The traditional forms of independently owned small business and co-operatives have lost significant market share and, in developed economies, the retail sector is now characterized by large-scale multiple chains run by powerful and sophisticated organizations. The increasing size of the retailers and the intensifying rates of competition in the markets in which they are operating have led retailers to search for new ways in order to develop their business. An acceleration of retail internationalization has occurred resulting in familiar logos, liveries, store fascias and retail formulas being found throughout the world. Retailing is now a dynamic industry.

Retailing is not only an integral part of the economic structure but also shapes, and is shaped by, the way of life. While the trading of goods has always been a part of traditional societies, in recent times the buying and selling of products has become a much more formalized and brand-dominated activity. Today the retail sector is 
increasingly viewed as an important activity in the economy and its impact on society in general is readily acknowledged. This acceptance of its importance is a reflection of a number of factors like its large and increasing contribution to the GDP. Its economic importance is more visible, it is a major employer. R etailers are gatekeepers and they are diversifying on an international scale, blurring the areas of retail to include wider areas of business activity and the size of operations allowing for supply chain control.

Centuries ago people found it difficult to get the things they needed to make their lives more comfortable. $M$ an had to hunt and kill animals for food and clothing. Then people started to exchange things. A fterwards, money came into use and people bought things instead of exchanging them with their friends and neighbours. This created a market place, where people came with money to buy the things they needed from others. These things were found in small stalls along the roadsides. The market place was convenient for people who lived in urban areas, but not for those who lived in rural areas. Both men and women started going to rural areas and sell their wares. These sellers were known as peddlers. They bought goods from the merchants and sold these goods to people in the rural areas.

As cities grew in size, the little roadside stalls became small, enclosed stores, where merchandise could be protected from bad weather and thieves. Then people started selling goods at one place for the convenience of the consumers to satisfy their needs. A number of retail outlets such as super bazaars, departmental stores, private retail shops, consumer cooperative stores, fair price shops and the like came into existence to distribute the required items. Generally, consumers tend to develop some sort of loyalty towards certain retail shops. The attitude towards various retail outlets mentioned above varies from consumer to consumer and from place to place.

\section{RETAILING OF GROCERIES IN BANGALORE CITY}

There are numerous grocery stores in Bangalore city. The grocery stores are local stores, departmental stores, co-operative stores and supermarkets. There are many local stores in Bangalore City. The departmental stores which are functioning in Bangalore City are Big Bazaar, Food World, Spencers, Shoppers Stop, Reliance Fresh, Greens Shop, Smart, M ota Foods and Stores Private Limited, N ature F resh, T otal M all, 9 to 9 Super M arket, Karnataka Fruits and Vegetables, Mysore Mini Super Market, Annapoorna Departmental Stores, A kshya Super M arket, Banashankari Super Bazaar, A pna Bazaar, Jayanagar Super Bazaar, Lake View Super Market, Koshy's Departmental Stores, New Food Land Super Market, N andini Departmental Stores, N oble Super Bazaar, O range Cash and Carry Super Market, Park View Departmental Stores, N ilgiris Super Market, Ideal Food World, A fzal Departmental Store, N amma Groceries, SLV Departmental Stores, SM Super Market, Veekay Departmental Store, Trinetra Super Retail Limited, Tirumala Provisions and General Stores, Sum Provisional Stores and Zam Provision Store. A mong the different types of grocery stores in Bangalore City, the Big Bazaar store occupies a dominant position. It has twelve branches in Bangalore City. The locations in which they are located are Indira N agar, Panashankarai, Koramangala, Jaya N agar, Malleshwara, J. P. N agar, Chamarajpet, BT M lay out, Rajaji N agar, Mahalakshmi lay out, Kalyan N agar and Basaveshwara N agar.

\section{SIG NIFICANCE OF THE STUDY}

There is no one in this world that is left out of the class of consumers. Immediately after a baby's arrival into this world there arises the need for the baby's foods, feeding bottle, oil, cloth, garments, medicines and the like. This brings the baby into the class of consumers. The consumer hood continues till one's last breath. So consumers are the key factor for the success of any marketing effort. Hence, the study on the purchasing pattern of consumers towards various retail outlets assumes significance. Indian consumers are a mixture of people with various levels of tastes, requirements and income. With advancement of science and technology production has become more sophisticated and a wide range of varieties are coming to the market. Such arrival in abundance has a two sided effect on consumers. O n one side, consumers are in an advantageous position to choose a brand of their liking. On the other hand, a consumer is confused to a certain level as to which brand to buy and make a profitable purchase. 
The present day's consumer has left behind a selfsufficient world and is now completely dependent on the market to meet his needs. Hence, purchasing becomes an inevitable activity in every family. Purchasing is a dynamic science and is the most important function of every family and a homemaker must devote time, attention and energy to it. As purchasing is a specialized activity the researcher is of the opinion that one should move with care and deliberation while making any purchase. The family as a consuming unit purchases a variety of goods and services to satisfy its wants and is always influenced by certain considerations which lead to selecting a particular commodity or retail outlet in preference to others. The popularity of these retail outlets is attributed to an unique factor that is "availability of wide range of a goods under one roof".

Bangalore, the electronic city of thick population of the high and middle-income group, holds great promise for the growth of retail outlets. At present there are a large number of retail outlets at different places both in the city and in the extension areas. This availability of a wide range of retail outlets has many difficulties for the families in the purchasing pattern of groceries, as of other items. It is the honesty and sincerity on the part of the businessmen and awareness and education on the part of consumers that help to understand the purchasing pattern.

The purchasing pattern consists of many decisions at every step and each family is unique in its way. The researcher strongly feels that the knowledge of the purchase pattern has immense significance in determining the economic life of the people who are the consumers and the masters of all trades. The study of the purchasing pattern is concerned not only with what consumers buy, but also with why they buy it, when, where and how. Hence, an attempt has been made by the researcher to study the purchasing behaviour of women grocery consumers in Bangalore city.

\section{OBJECTIVES OF THE STUDY}

The following are the specific objectives of the study.

1. To evaluate the pattern of grocery retailing in Bangalore city.
2. To determine the women consumer's choice of grocery retail shops.

3. To examine the feasible way of procuring / purchasing quality goods at economical rates.

4. To examine the buyer's behaviour in the choice of the groceries and

5. To evaluate the pattern adopted by the women consumers in the purchase of grocery.

\section{SCOPE OF THE STUDY}

The important task of any consumer is the purchase of groceries in the stores. The purchase behaviour includes the selection of the store and the selection of the brand by the consumers. The present study analyses the purchase behaviour of the women grocery consumers with special reference to Bangalore city. The study was related to the socio-economic background of the consumers like age, income level, educational status and occupation. This study enables us to learn about the various stores in Bangalore, brand awareness among the consumers and their purchase behaviour.

\section{METHODOLOGY}

The present study was based on both primary and secondary data. Primary data are those which are collected afresh and for the first time and original in character. Therefore, primary data was collected with the help of the interview method by using a structured questionnaire. The interview contained relevant questions based on the objectives of the study. Secondary data are those which have already been collected by someone else and which have already been passed through the statistical process. The secondary data for the study were collected through books, periodicals, magazines, newspapers, journals, published and unpublished theses and web portals. The collected data were properly edited, coded and classified according to the requirements of the study. The necessary tables were formed through the classification of data.

A structured questionnaire was used as a tool for collecting the data for the project. The questionnaire contained four major parts. The questionnaire was first filled by a few respondents to check whether the questions led to the objectives. The questionnaire was partially changed by adding, deleting, reforming few 
questions and again retested and data collection was continued after ensuring the questionnaire conform to the objectivity of the result from the modified questionnaire. The researchers used the interview schedule method to collect the primary data. The target respondents were briefed about the research and the mode of filling up the questionnaire. The researchers made no attempt to influence or bias the opinions or feelings of the target respondents. The study was conducted from December 2011 to A ugust 2012. Since the population of the selected area for the research is Bangalore city and could not be interviewed with the given time and cost limitations, only selected samples have been taken for the research. O ne $\mathrm{H}$ undred and Fifty samples have been selected and the Random Sampling $M$ ethod is employed by the researchers for the purpose. The primary data collected from the potential respondents from different areas have been sorted, classified, edited, tabulated in a proper format and analyzed by deploying appropriate statistical tools. The collected data are analyzed through Percentage A nalysis, Chi-square test, Garrett's Ranking, Weighted A verage, Y ule's C oefficient of A ssociation, t-test and C o-efficient of $\mathrm{V}$ ariation.

\section{REVIEW OF LITERATURE}

Kollat and Willett conducted a study of "Customer Impulse Purchasing Behaviour" in the Super Market setting. The objectives of this study were to determine consumer's susceptibility to impulsive or unplanned purchasing, and also to find out the conditions and consumer characteristics that lead to unplanned purchasing. From the study it was found that unplanned purchasing was frequent among consumers. Customer characteristics did not have any relationship with unplanned purchasing. The inducements, which came from the display of the goods and the customer's tendency to not to plan their purchase, were the possible conditions which led to unplanned purchasing.

Ramakrishan $\mathbf{R}$ ao and $\mathbf{R}$ ama Prasad in their study titled "A Case Study of Consumers Attitude towards Fair Price Shops" has discussed the consumer's attitude to the working of the fair price shops and the problems of the consumers. They stated that though public distribution system performed the important function of distributing essential commodities to the vulnerable section of the society, the system has may weaknesses.

Subrahmanyam et al have studied about the "M arketing Structure and Super Bazaar - A C ase Study of Visakhapatnam Steel City". The objective of the study was to find the preferences of the consumers for different consumer goods in retail outlets. Further they examined the attitude of the consumers to super bazaars in that city. They found that super bazaars were far from their residence. It was also observed that there was no difference between the super bazaars and the private shops in the view of the consumers. They have suggested that super bazaars could employ some sales representatives to increase their sales volume.

Whan Park et al have made a study on "The Effects of Situational Factors on In-store Grocery Shopping Behaviour: The Role of Store Environment and Time A vailable for Shopping". They ascertain the effects of two situational factors, store knowledge and time available for shopping on consumer's grocery shopping behaviour. The results indicate that these two factors have an impact on such shopping behaviour as failure to make the intended purchases, unplanned buying, brand and product class switching and purchase volume deliberation. They have suggested that the information processing activities that mediate these relationships differ across shopping conditions. Implications for managing the grocery store environment that may advance current practice are explained.

Murali and Kulkarni in their study titled "A wareness of Housewives Regarding Food Adulteration" have analyzed the awareness of food adulteration among housewives. This study showed the food purchasing pattern of families. The main responsibility of a housewife was to maintain the sound health of the family with nutritious food stuff. Further they suggested preventing food adulteration by purchasing of food stuff from well reputed shops. People should be educated regarding the ill effects of food adulteration.

Rosemary and Colin have conducted a research on "The Retail Revolution, the Carless Shoppers and Disadvantages. The spatial restructuring of retailing in the British cities in recent years has been characterized as a retail revolution. O ff-centre superstores, retail 
warehouses, and planned regional shopping centers have been added to the pattern of traditional shopping facilities, which in turn have often experienced decline. The dichotomy between the old and the new shopping facilities is increasingly reflected in the market inequality in the opportunities of consumers, in which those with poor mobility are seen as disadvantaged consumers. Investigation of household shopping behaviour in the Swansea area following the recent development of many new car-oriented facilities shows that mobility, specifically car-ownership and the DIY products, and also for more specialized goods on sale at off-centre locations. The attractions of the newer off-centre opportunities dominate the shopping behaviour of the car-owning households. By contrast, the carless shopper appears constrained in behaviour and largely bypassed by the retail revolution.

Susan et al have made a study of 'Consumers' Perceptions of the Assortment Offered in a Grocery Category: The Impact of Item Reduction". The authors examined how consumers form assortment perceptions in the face of stock keeping units reduction with a particular emphasis on two heuristic cues: the availability of a favourite product and the amount of shelf space devoted to the category. The results indicated that retailers might be able to make substantive reductions in the number of items carried without negatively affecting assortment perceptions and store choice, as long as only low-preference items are eliminated and category space is held constant.

Michelle and Brenda have carried out a study on "C onsumer Response to O nline Grocery Shopping", for the preliminary assessment of consumer response to a demand for online food retail channels. Data were collected from 243 U S consumers who currently bought their groceries online. The majority of online users were less than 55 years of age, women with reported annual incomes of $\$ 70,000$ or more. O ver $70 \%$ reported convenience and saving time as their primary reasons for buying groceries online but $15 \%$ cited physical or constraint issues that made it difficult for them to shop at grocery stores. $\mathrm{N}$ ineteen per cent bought all of their groceries online. The study also reports demographic and online shopping variables that are significantly related to the primary reasons for shopping online, willingness to buy all grocery items online, perception of time spent shopping online is in the store, and experience with online grocery shopping.

Maria et al have carried out a research on "Diversity in Deprivation: Exploring the Grocery Shopping Behaviour of Disadvantaged Consumer". The study was conducted in a deprived residential area in Scotland. The researchers characteristized the respondents as economic shoppers, they were heavily dependent on the local convenience stores, mainly due to the financial and mobility restrictions they faced. It was found that the experience of social exclusion was not homogenous, within the sample, varying with other aspects of disadvantage, including social support networks, on illness, age, family situation and mobility.

\section{LIMITATIONSOF THE STUDY}

1. The study is restricted to a specified area, namely Bangalore city. Therefore the findings may not be applicable to other areas.

2. D ue to resource constraints the analysis was limited to a sample size of 150 women grocery consumers only, which is not quite representative.

3. Due to limited area, the researcher has taken limited retail outlets and

4. Due to numerous brands of grocery, the researcher has taken only limited brands for the study.

\section{AN ALYSIS AND INTERPRETATION OF DATA}

The data collected through the well structured questionnaire was analyzed and the interpretations made on the basis of such analysis are represented below:

\section{(IN SERT TABLE 1 HERE)}

It is observed from Table 1 that a majority of the respondents (40 per cent) fall in the age group of 40-50 years. To be specific, 25 per cent are in the age group of 30-40 years and 23 per cent in the age group of 20-30 years. The least percentage of respondents (12 per cent) is in the above 50 years age group. Forty two per cent have only secondary education, 33 per cent of the respondents have college education and 25 per cent of the respondents have higher secondary education. Seventy two per cent are house wives and only 28 per 
cent of them fall under the category of employed women. Eighty nine per cent belong to nuclear families and 11 per cent belong to joint families. The table shows that a majority of the respondents 58 per cent have income below Rs.10,000, 27 per cent have income between Rs.10,000 and Rs.20,000, 11 per cent have income above Rs.30,000 and 4 per cent have income between Rs.20,000 and 30,000.

(IN SERT TABLE 2 HERE)

It is noticed from Table 2 that out of the 150 respondents, 26 buy from any store and 124 buy from a particular store. $\mathrm{O}$ ut of those who buy from a particular store, 48 have chosen a local store, 61 have chosen a departmental store, 11 have chosen a co-operative store and 4 have chosen a super market to buy grocery from.

(IN SERT TABLE 3 HERE)

t-significance value below 0.05 indicates facilities with significant difference between the local stores and the organized stores. Door delivery, self-service, discount for heavy purchase, payment by cards, credit facility and packed goods are the various facilities with significant difference between local stores and organized store and hence the hypothesis is rejected for these facilities. A mong the facilities with significant difference between the local and the organized stores, the perception of the respondents is in favour of the local stores in credit facility alone whereas in all other facilities the organized stores are favoured. The t-test makes it clear that there is no significant differences between the local and the organized stores in two facilities namely offer of different brand of groceries and policy of replacing defective goods. H ence, the hypothesis is accepted for these facilities.

\section{(IN SERT TABLE 4 HERE)}

Table 4 shows that among the five attributes that influence the choice of store, the co-efficient of variation is the least for the attribute "reasonable price" (0.143), followed by "good quality" (0.161), "variety and assorted goods" (0.172), "attractive display" (0.183) and "sales promotion schemes" $(0.387)$. So it can be concluded from the Table that the attribute reasonable price is one that influences the choice of the stores to the greatest extent, followed by good quality, variety and assorted goods, attractive display and sales promotion schemes in that order.

\section{(IN SERT TABLE 5 HERE)}

Table 5 shows the ranking of the reasons for switch over of the store. The first rank is given to quality of goods, the second rank is given to low price, the third rank is given to variety of goods and the fourth rank is given to the availability of branded goods.

\section{(IN SERT TABLE 6 HERE)}

Table 6 explains the ranking of the sources of information of the brands of grocery items. Garrett's ranking finds out that the first rank is given for advertisement, the second rank goes to display in shops, the third rank is allotted to information from friends / neighbours, the fourth rank is assigned to samples and trial packs provided and salesman's suggestion gets the fifth place.

\section{(IN SERT TABLE 7 HERE)}

Table 7 explains the ranking of "The M otivating Factors for Choice of Brand". Garrett's Ranking finds that the first rank is for personal experience, the second rank is for family decision, the third rank is for advertisement, the fourth rank is for friend's / colleagues' suggestion and the fifth rank is for sal esman's suggestion.

\section{(IN SERT TABLE 8 HERE)}

It is seen from Table 8 that most of the respondents prefer home made powder for wheat flour (62 per cent), chilly powder (79 per cent), coriander powder (81 per cent) and most of the respondents prefer branded powder for turmeric powder (67 per cent), bengal gram flour (87 per cent) and garam masala powder (69 per cent).

\section{Relationship between Age G roup and $U$ se of Home Made / Branded Powder for Wheat Flour}

A study is made to find the relationship between the age group of the respondents and the use of homemade / branded wheat flour. A hypothesis is framed and tested with the help of the $C$ hi-square test. 
(IN SERT TABLE 9 HERE)

$\mathbf{N}$ ull H ypothesis: There is no relationship between the age group and the use of homemade / branded powder of wheat flour.

A s the calculated Chi-square value (4.54) is less than the table value (7.81) at 5\% level of significance for 3 degrees of freedom, the null hypothesis is accepted and it could be concluded that there is no relationship between the age group and the use of homemade / branded powder for wheat flour.

Relationship between Age Group and $U$ se of H omemade / Branded Powder F or Chilly Powder

A study is made to find the relationship between the age group and the use of homemade / branded chilly powder by the respondents. A hypothesis is framed and tested with the help of the $\mathrm{C}$ hi-square test.

\section{(IN SERT TABLE $10 \mathrm{HERE}$ )}

$\mathbf{N}$ ull $\mathbf{H}$ ypothesis: There is no significant relationship between the age group and the use of homemade / branded powder for chilly powder.

As the calculated C hi-square value (0.95) is less than the table value (7.81) at $5 \%$ level of significance for 3 degrees of freedom, the null hypothesis is accepted and it could be concluded that there is no significant relationship between the age group and the use of homemade / branded powder for chilly powder.

Relationship between Age Group and $U$ se of H omemade / Branded Powder for Bengal Gram Flour

A study is made to find the relationship between the age and the use of homemade / branded bengal gram flour of the respondents. A hypothesis is framed and tested with the help of the $\mathrm{C}$ hi-square test.

\section{(IN SERT TABLE 11 H ERE)}

N ull H ypothesis: There is no association between the age group and the use of homemade / branded powder for Bengal gram flour.
As the calculated Chi-square value (2.61) is less than the table value (7.81) at 5\% level of significance for 3 degrees of freedom, the null hypothesis is accepted and it could be concluded that there is no association between the age group and the use of homemade / branded powder for Bengal gram flour.

Relationship between Type of Family and $U$ se of H omemade/ Branded Powder for Wheat Flour

To find the association between the type of family and the use of branded / non-branded powder for wheat flour, Y ule's C o-efficient of A ssociation is calculated.

(IN SERT TABLE 12 HERE)

$$
Q=\frac{(A B)(a b)-(A b)(a B)}{(A B)(a b)+(A b)(a B)}=0.2686
$$

Thus, there is little positive association between the type of family and the use of branded / non-branded wheat flour. H ence, it is concluded that only a small percentage of the joint families use branded wheat flour.

\section{Relationship between Type of Family and $U$ se 0 f H omemade / Branded Chilly Powder}

To find the association between the type of family and the use of branded / non-branded chilly powder, Y ule's C o-efficient of A ssociation cal culated.

(IN SERT TABLE 13 HERE)

$$
Q=\frac{(A B)(a b)-(A b)(a B)}{(A B)(a b)+(A b)(a B)}=-0.637
$$

There is a high degree of negative association between the type of family and the choice of branded / nonbranded chilly powder. Hence it is concluded that most of the joint families use non-branded chilly powder.

Relationship between Type of Family and $U$ se of H omemade / Branded Bengal Gram Flour

To find the association between the type of family and the use of branded / non-branded Bengal gram flour, Y ule's C o-efficient of A ssociation cal culated.

(IN SERT TABLE 14 HERE) 


$$
Q=\frac{(A B)(a b)-(A b)(a B)}{(A B)((a b)+(A b)(a B)}=0.0413
$$

Thus, there is very little positive association between the type of family and branded / non-branded bengal gram flour. It is concluded that very few joint families use branded bengal gram flour.

\section{(IN SERT TABLE 15 HERE)}

Table 15 shows the ranking for the 'reasons for switch over of brand'. The weighted average method is used and the first rank is given to better quality, the second rank is given to small packs, the third rank to better price and the fourth rank to non-availability of the previous brand.

\section{(IN SERT TABLE 16 HERE)}

t-significance value below 0.05 indicates those factors with significant difference between the influence on housewives and employed women. Discounts, free gifts, duration of shelf life and small packs are the factors which influence the two groups, housewives and employed women, in significantly different ways. Hence, the hypothesis is rejected for these factors. Employed women give more importance to discount, free gifts, duration of shelf life and small packs than housewives do. The factors like attractive packing, low price and quality of goods have the same level of influence on both the groups, housewives and employed women. $\mathrm{H}$ ence the hypothesis is accepted for these factors.

\section{Relationship between $O$ ccupation and Pattern of} Purchase by the Respondents

A study is made to find the relationship between the occupation and the purchase pattern of the respondents. A hypothesis is framed and tested with the help of the Chi-square.

\section{(IN SERT TABLE 17 HERE)}

$\mathbf{N}$ ull $\mathbf{H}$ ypothesis: There is no relationship between the occupation and the pattern of purchase by the respondents.
As the calculated Chi-square value (2.78) is less than the table value (3.84) at $5 \%$ level of significance for 1 degree of freedom, the null hypothesis is accepted and it could be concluded that there is no relationship between the occupation and the pattern of purchase.

\section{Relationship between Monthly Income and Pattern of Purchase By The Respondents}

A study is made to find the relationship between the monthly income and the pattern of purchase of the respondents. A hypothesis is framed and tested with the help of the Chi-square. Yate's correction is also employed.

\section{(IN SERT TABLE 18 HERE)}

$\mathbf{N}$ ull $\mathbf{H}$ ypothesis: There is no relationship between the level of the monthly income and the pattern of purchase.

As the calculated Chi-square value (4.54) is less than the table value (7.81) at $5 \%$ level of significance for 3 degrees of freedom, the null hypothesis is accepted and it could be concluded that there is no relationship between the level of income and the pattern of purchase.

(IN SERT TABLE 19 HERE)

Table 19 shows the ranking for the reasons for purchase in small lots. The W eighted average method is used and the first rank is given to convenience, the second rank is given to economical, the third rank is given to control over consumption and the fourth rank is given to easy to determine quantity.

\section{(IN SERT TABLE $20 \mathrm{HERE}$ )}

Table 20 shows the ranking for the reasons for purchase in bulk and the first rank is given to economic, the second rank is given to convenience, the third rank is given to possibility of door delivery and the fourth rank is given to control over quantity.

\section{Relationship Between Occupation And Persons Involved In Purchasing}

A study is made to find the relationship between the occupation of the respondents and the persons involved 
in purchasing the groceries of the respondents. A hypothesis is framed and tested with the help of the $\mathrm{Chi}$ square test.

\section{(IN SERT TABLE 21 HERE)}

$\mathrm{N}$ ull $\mathbf{H}$ ypothesis: There is no relationship between the occupation of the respondents and the persons involved in purchasing.

As the calculated Chi-square value (0.64) is less than the table value (3.84) at $5 \%$ level of significance for 1 degree of freedom, the null hypothesis is accepted and it could be concluded that there is no relationship between the occupation of the respondents and persons involved in purchasing.

\section{Relationship between Education and A wareness of Consumer Rights}

A $n$ attempt is made to identify the relationship between the education of the respondents and their awareness of consumer rights. A hypothesis is framed and tested with the help of the $\mathrm{C}$ hi-square test.

\section{(IN SERT TABLE 22 HERE)}

N ull H ypothesis: There is no relationship between the education and the aw areness of consumer rights.

A s the calculated Chi-square value (41.77) is less than the table value (5.99) at $5 \%$ level of significance for 2 degrees of freedom, the null hypothesis is rejected and it could be concluded that there is a relationship between the education of the respondents and their awareness of consumer rights.

\section{SU G GEST IO N S}

1. Bangalore is the Capital of Karnataka State. A considerable part of the population is literate and many of them are working. The escalating number of middle class families and the growing number of working women are the other stimulating features for the growth of retail outlets in Bangalore. Groceries are products of necessity and the city is crowded with local kirana shops, departmental stores and co-operative stores selling grocery along with stationery. But there is only one supermarket that is $\mathrm{N}$ ew Food Land. The big retail outlets like Shopper's Stop, Nilgris, Food World and the like may be requested to extend their services to Bangalore city so that the consumers may enjoy the benefit of assortment of goods at competitive prices.

2. Consumers are getting accustomed to buy from the departmental stores and so the departmental stores in Bangalore may be suggested to branch out to the various areas in the length and breadth of the city. As most of the women consumers prefer to buy from the nearby stores, the local stores may be suggested to set up their shops near residential quarters like flats, apartments and the like.

3. Most of the stores offer cash sales and credit sales. With the advancement of banking facilities in the globalised era, many consumers prefer to pay using the credit cards. So the retail outlets in Bangalore may provide the consumers the facility of payment by card.

4. It is a welcome feature that most of the consumers are aware of branded grocery products and specify the brands when they make purchases. The grocery manufacturing companies may improve their advertisements and sales promotion techniques to motivate more and more consumers to go for branded grocery products and branded grocery powdered products.

5. A mong the companies that manufacture grocery products, Hindustan Lever Limited is not yet popular. Its products like 3 Roses, Taj Mahal, Red Lable, T aaza, BRU , Green Lable and the like are not well known among the consumers of Bangalore. $H$ ence, it is suggested that the company enhances its publicity.

6. For grocery products which are consumed in bulk quantities, like rice and pulses, only the local brands are popular among the consumers. It is suggested that the big manufacturing companies and the retail outlets take necessary steps to popularize the established non-local brands. The salesmen may also be advised to inform the consumers on the availability of the various brands for rice and pulses.

7. Women grocery consumers are not by and large aware of the consumer rights. Even those who are aware of their rights hesitate to take action against adulteration and other malpractices. It is suggested that the NGOs, the educational institutions and the 
consumer forums educate the consumers and motivate them to take action against erring grocery stores and grocery manufacturing companies.

\section{CONCLUSION}

The opportunity for watching women choose the shops for making their grocery purchases was very interesting both as an experience and as education. The observation of the process has to be almost an indispensable part of the training of a research scholar. It helps her realize the way in which theories in social and management sciences are based on the realities of individual and social behaviour. The ability to trace the patterns behind what are the traits of individual behaviour by expanding one's area of observation from individuals to groups is necessary for any one who would be a business person, an administrator of any kind or an executive. In that way this project work has been an exhilarating experience. It has enabled the researchers to identify the areas in which further research will be useful and rewarding. For instance, there could be studies in all products and requirements of the domestic business sector. It should be informative to try to find out how modernization percolates from metropolitan to big cities, towns and villages. The study has enabled the researcher to gain the confidence that she could train in industrial and business organization, as an organizer and counsellor.

\section{REFERENCES}

1. Jae Eun Chung, Jong Pil and Dwan Thorndike Pysarchik, "C ue U tilisation to A ssess food Product Quality: A Comparison of Consumers and Retailers in India", The International Review of Retail, Distribution and Consumer Research, Vol. 16, No. 2, M ay 2006, pp. $199-214$.

2. Kollat D. T and Willett R. P, "C ustomer Impulse Purchasing Behaviour", Journal of Marketing Research, Vol. 4, 1967, pp. 21 - 31.

3. Kulkarni M. S and Murali, D, "Study of Purchasing Practices of Consumers of Farbhani Town", Indian Journal of Marketing, Vol. XXV, No. 2 - 3, February - March 1996, pp. 3 - 7.

4. Maria Piacentini, Sally Hibbert, $\mathrm{H}$ aya AI - Dajani, "Diversity in Deprivation: Exploring the Grocery Shopping of Disadvantaged Consumer", The
International Review of Retail, Distribution and Consumer Research, Vol. II, N 0. 2, A pril 2001, pp. $141-158$.

5. M aruthamuthu, $K$, Krishnamumar, $K$ and Vasan $M$., "Consumer Behaviour and Brand Preference of Britannia Biscuits - An Empirical Study with Reference to Salem, T amil N adu", Indian Journal of Marketing, Vol. XXXVI, N o. 8, August 2006, pp. $17-21$.

6. Michelle Morganosky A and Brenda Cude J, "Consumer Response to Online Grocery Shopping", International Journal of Retail and Distribution Management, $\mathrm{V}$ ol. 28, N o. 1, February 2000, pp. 17 - 26.

7. Murali D, and Kulkarni, M. S, "A wareness of H ousewives Regarding Food A dulteration", Indian Journal of Marketing, Vol. XX, No. 5, January 1990, pp. 27 - 29.

8. Murali D, and Kulkarni M. S, "Study of Purchasing Practices of C onsumers of Parbhani Town", Indian Journal of Marketing, Vol. XXV, No. 2 - 3, February - M arch 1996, pp. 21 - 23

9. Nagaraja B, "Consumer Behaviour and A wareness with Special Reference to Edible Oil Users - A Study", Indian Journal of Marketing, Vol. XXXV, N o. 3, March 2005, pp. 18 - 21.

10. N irmal Gupta K, "Consumer Behaviour in Restaurants and its Importance in Marketing Planning - A Study of Delhi based 5 - Star Restaurants", Indian Journal of Marketing, Vol. XVII, N o. 4, A pril 1986, pp. 24 - 25.

11. Ramakrishnan Rao S, and Rama Prasad Rao, H, "A Case Study of Consumers Attitude Towards Fair Price Shops", M anagement, June 1982, pp. 21 - 22.

12. Ramana, A. V, and Viswanath, P, "Consumer Behaviour and $A$ wareness with Special Reference to Edible Oil Users - A Study", Indian Journal of M arketing, Vol. XXXV, N o. 3, March 2005, p. 35.

13. Ramasamy K, Kalaivanan G, and Sukumar, S, "Consumer Behaviour Towards Instant Food Products", Indian Journal of Marketing, Vol. XXXV, N o. 6, January 2005, pp. 24 - 25.

14. Rosemary Bromley, D. F, and Colin Thomas J, "The Retail Revolution, the Careless Shopper and Disadvantages, Transactions of the Institute of British Geographers", N ew Series, Vol. 18, N o. 2, 1993, pp. $222-236$.

15. Sarwade W. K, "Retail Trade Structure in Rural 
A rea", Indian J ournal of M arketing, Vol. XXV, $\mathrm{N}$ o. 8 - 10, A ugust - 0 ctober 2000, pp. 26 - 36.

16. Subrahmanyam G, Ramakrishna B, and Rama M ohana K, "M arketing Structure and Super Bazaar - A Case Study of Visakhapatnam Steel City", Indian Journal of Marketing, Vol. XII, No. 12, A ugust 1982, pp. 9 - 14.

17. Susan Broniarczyk M, Wayne Hoyer D, and H eigh Mc Alister, "Consumers' Perceptions of the Assortment Offered in a Grocery Category: The Impact of Item Reduction", Journal of Marketing Research, Vol. 35, N o. 2, M ay 1998, pp. 166 - 176.
18. Vincent - Wayne Mitchell, Greg Harries, "The Importance of Consumers' Perceived Risk in Retail Strategy", European Journal of Marketing, Vol. 39, N o. 7 / 8, January 2005, pp. 821 - 837.

19. Whan Park C, Easwar S Iyer, and D aniel C. Smith, "The Effects of Situational Factors on In-store Grocery Shopping Behaviour: The Role of Store Environment \& Time Available for Shopping", Journal of Consumer Research, Vol. 15, No. 4, M arch 1989, pp. 422 - 433.

Table 1: Composition of the Sample of R espondents

\begin{tabular}{|c|c|c|c|}
\hline SI. No. & Profile of the Respondents & N umber of Respondents & Percentage \\
\hline \multirow[t]{5}{*}{1.} & AGE GROUP & & \\
\hline & $20-30$ years & 34 & 23 \\
\hline & 30 - 40 years & 37 & 25 \\
\hline & $40-50$ years & 60 & 40 \\
\hline & A bove 50 years & 19 & 12 \\
\hline \multirow[t]{4}{*}{2.} & EDUCATIONALQUALIFICATION & & \\
\hline & Secondary Education & 63 & 42 \\
\hline & $\mathrm{H}$ igher Secondary Education & 38 & 25 \\
\hline & College Education & 49 & 33 \\
\hline \multirow[t]{3}{*}{3.} & $\overline{O C} \overline{C U} \overline{P A} \overline{T I O N}$ & & \\
\hline & H ousewives & 108 & 72 \\
\hline & Employed & 42 & 28 \\
\hline \multirow[t]{3}{*}{4.} & TYPE OF FAMILY & & \\
\hline & Joint & 16 & 11 \\
\hline & N uclear & 134 & 89 \\
\hline \multirow[t]{5}{*}{5.} & MONTHLY INCOME & & \\
\hline & Below Rs.10,000 & 87 & 58 \\
\hline & Rs. 10,000 - Rs. 20,000 & 41 & 27 \\
\hline & Rs. 20,000 - Rs.30,000 & 6 & 4 \\
\hline & A bove Rs.30,000 & 16 & 11 \\
\hline
\end{tabular}

Source: Primary Data 
Table 2: C hoice of G rocery Store

\begin{tabular}{|c|c|c|c|}
\hline SI. No. & Type of Stores & $\mathrm{N}$ umber of R espondents & Percentage \\
\hline 1. & Any Store & 26 & 17 \\
\hline 2. & Particular Store: Local Store & 48 & 32 \\
\hline 3. & Department Store & 61 & 41 \\
\hline 4. & Co-operative Store & 11 & 7 \\
\hline 5. & Super $M$ arket & 4 & 3 \\
\hline & Total & 150 & 100 \\
\hline
\end{tabular}

Source: Primary Data

Table 3: Perception Of C onsumers Regarding The Facilities 0 ffered By The Stores

\begin{tabular}{|c|c|c|c|c|c|}
\hline \multirow[t]{2}{*}{ SI. N o.I } & \multirow[t]{2}{*}{ Facilities } & \multicolumn{2}{|l|}{ IMean } & \multirow[t]{2}{*}{ T-value } & \multirow{2}{*}{$\begin{array}{l}\text { t-Significance } \\
\text { (2-tailed) }\end{array}$} \\
\hline & & Local Store & O rganized Score & & \\
\hline 1. & Door Delivery & |1.23 & 2.13 & $6.321^{*}$ & 0.000 \\
\hline 2. & Self - Service & 1.00 & 1.71 & $5.512 *$ & 0.000 \\
\hline 3. & Discount for $\mathrm{H}$ eavy Purchase & 1.27 & 1.95 & $5.017^{*}$ & 0.000 \\
\hline 4. & Payment by Vards & 1.00 & 1.37 & $3.266^{*}$ & 0.001 \\
\hline 5. & Credit Facility & 1.17 & 1.00 & $3.867^{*}$ & 0.000 \\
\hline 6. & Packed Goods & 2.66 & 2.72 & $2.104 *$ & 0.037 \\
\hline 7. & Variety of Brands & 2.83 & 2.68 & 1.553 & 0.123 \\
\hline 8. & Replacement of D efective Goods & 2.85 & 2.93 & 1.469 & 0.144 \\
\hline
\end{tabular}

* Significant at 0.05 level of significance

Table 4: 0 pinion of C onsumers Regarding the Attributes of the Stores

\begin{tabular}{|c|c|c|c|c|c|}
\hline SI. N o. & Attributes & Mean & $\begin{array}{l}\text { Standard } \\
\text { D eviation }\end{array}$ & $\begin{array}{l}\text { C o-efficient of } \\
\text { Variation }\end{array}$ & Rank \\
\hline$\overline{1}$. & Reasonable Price & $\overline{4} . \overline{113}$ & $\overline{0.587}$ & $0 . \overline{14} \overline{3}$ & $\bar{I}$ \\
\hline 2. & Variety and A ssorted G oods & 4.161 & 0.714 & 0.172 & III \\
\hline 3. & Attractive Display & 3.766 & 0.688 & 0.183 & IV \\
\hline 4. & Good Q uality & 4.137 & 0.667 & 0.161 & II \\
\hline 5. & Sales Promotion Schemes & 2.653 & 1.028 & 0.387 & $\mathbf{v}$ \\
\hline
\end{tabular}

Source: Primary Data 
Table 5: R anking for the R easons of Switch O ver of the Store

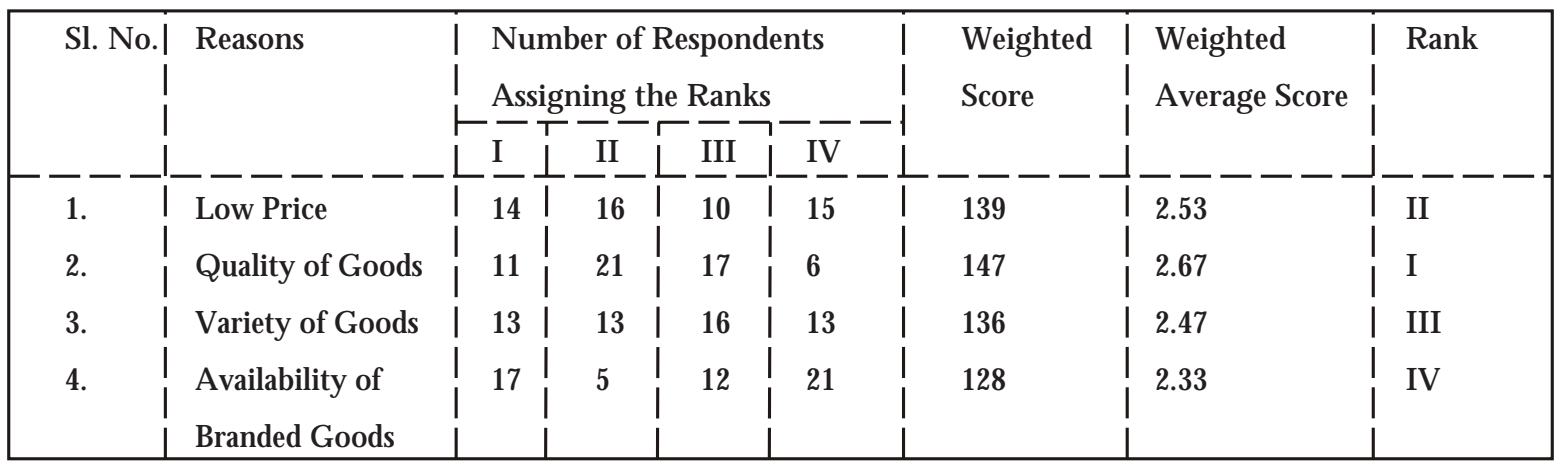

Source: Primary Data

Table 6: R anking for the Sources of Information about Brand of G roceries

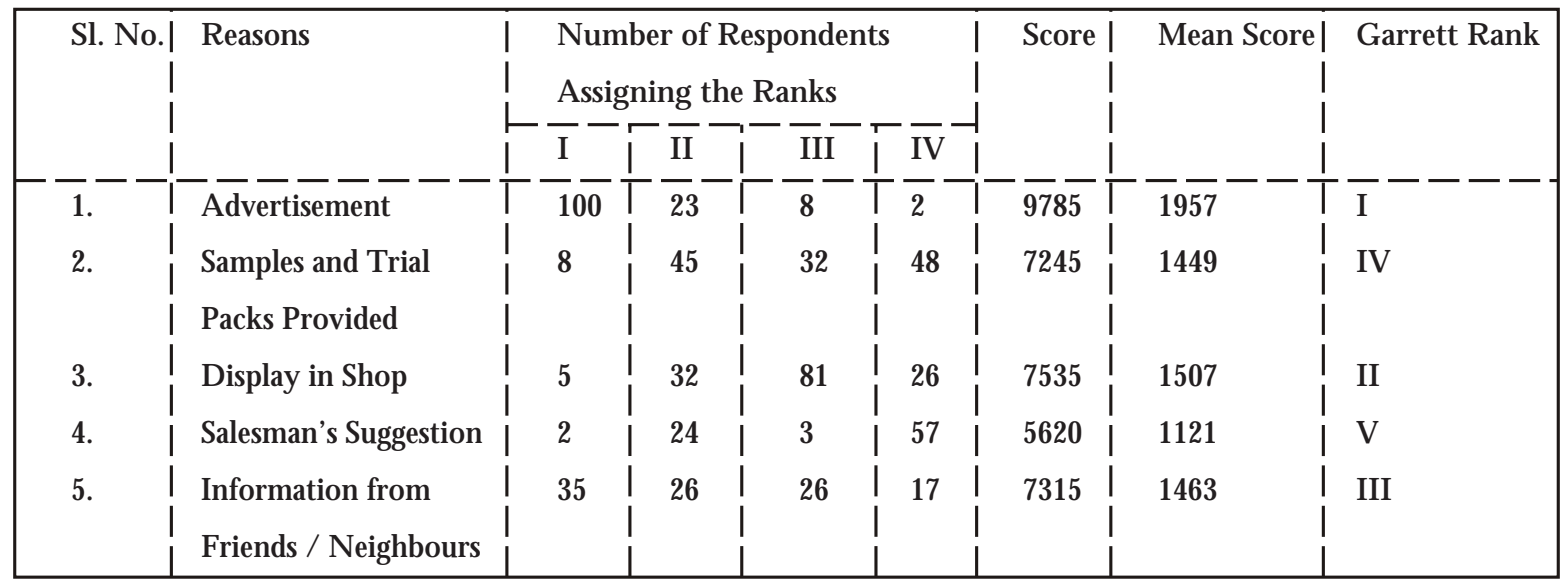

Source: Primary Data

Table 7: R anking of M otivating Factors for $\mathrm{C}$ hoice of Brand

\begin{tabular}{|c|c|c|c|c|c|c|c|c|c|}
\hline \multirow[t]{2}{*}{ SI. No. } & \multirow[t]{2}{*}{ Reasons } & \multicolumn{5}{|c|}{$\begin{array}{l}\text { N umber of R espondents } \\
\text { A ssigning the R anks }\end{array}$} & \multirow[t]{2}{*}{ Score } & \multirow[t]{2}{*}{ Mean Score } & \multirow[t]{2}{*}{ G arrett $\mathbf{R}$ ank } \\
\hline & & 1 & II & $\overline{I I I}$ & IV & $\overline{\mathbf{V}}$ & & & \\
\hline 1. & Friends' / Colleagues' & 16 & 24 & 35 & 48 & 27 & 6985 & 1397 & IV \\
\hline & Suggestion & & & & & & & | & \\
\hline 2. & Family Decision & 33 & 62 & 29 & 22 & 6 & 8675 & 1735 & II \\
\hline 3. & A dvertisement & 24 & 20 & 56 & 441 & 3 & 7675 & 1535 & III \\
\hline 4. & Salesman's Suggestion & 5 & 14 & 6 & 26 & 99 & 5030 & 1006 & V \\
\hline 5. & Personal Experience & 72 & 30 & 21 & 12 & 15 & 9105 & 1821 & I \\
\hline
\end{tabular}

Source: Primary Data 
Table 8: D etails about C onsumption of G rocery Powders

\begin{tabular}{|c|c|c|c|c|}
\hline \multirow[t]{2}{*}{ SI. N o. } & \multirow[t]{2}{*}{ G rocery Powder } & \multicolumn{2}{|c|}{ N umber of Respondents } & \multirow[t]{2}{*}{ Total } \\
\hline & & H ome M ade Powder & Branded Powder & \\
\hline 1. & Wheat Flour & $93(62)$ & $57(38)$ & $150(100)$ \\
\hline 2. & Chilly Powder & $118(79)$ & $32(21)$ & $150(100)$ \\
\hline 3. & Coriander Powder & $122(81)$ & $28(19)$ & $150(100)$ \\
\hline 4. & Turmeric Pow der & $50(33)$ & $100(67)$ & $150(100)$ \\
\hline 5. & Bengal Gram Flour & $20(13)$ & $130(87)$ & $150(100)$ \\
\hline 6. & Garam M asala Powder & $47(31)$ & $103(69)$ & $150(100)$ \\
\hline
\end{tabular}

Source: Primary Data

Table 9: A ge Group and U se of $\mathrm{H}$ ome Made / Branded Powder for Wheat Flour

\begin{tabular}{|c|c|c|c|c|}
\hline \multirow[t]{2}{*}{ SI. No. } & \multirow[t]{2}{*}{ Age Group } & \multicolumn{2}{|c|}{$\mathrm{N}$ umber of R espondents } & \multirow[t]{2}{*}{ Total } \\
\hline & & H ome M ade & Branded & \\
\hline 1. & $20-30$ years & 24 (21.08) & $10(12.92)$ & 34 \\
\hline 2. & 30 - 40 years & 25 (22.94) & 12 (14.06) & 37 \\
\hline 3. & 40 - 50 years & $36(37.20)$ & $24(22.80)$ & 60 \\
\hline 4. & A bove 50 years & 8 (11.78) & 11 (7.22) & 19 \\
\hline & Total & 93 & 57 & 150 \\
\hline
\end{tabular}

Source: Primary Data (F igures in brackets represent the expected frequency)

Table 10: Age Group and U se of H omemade / Branded Powder for Chilly Powder

\begin{tabular}{|c|c|c|c|c|}
\hline Sl. No. & Age G roup & H ome M ade & $\frac{\text { lents }}{\text { Branded }}$ & Total \\
\hline 1. & 20 - 30 years & $26(26.75)$ & $8(7.25)$ & 34 \\
\hline 2. & 30 - 40 years & $28(29.11)$ & $9(7.89)$ & 37 \\
\hline 3. & $40-50$ years & $48(47.20)$ & $12(12.80)$ & 60 \\
\hline 4. & A bove 50 years & 16 (14.95) & $3(4.05)$ & 19 \\
\hline & Total & 118 & 32 & 150 \\
\hline
\end{tabular}

Source: Primary Data (Figures given in the brackets represent the Expected F requency)

Table 11: A ge Group and U se of H omemade / Branded Powder for Bengal G ram Flour

\begin{tabular}{|c|c|c|c|c|}
\hline \multirow[t]{2}{*}{ SI. No. } & \multirow[t]{2}{*}{ Age G roup } & \multicolumn{2}{|c|}{$\mathrm{N}$ umber of R espondents } & \multirow[t]{2}{*}{ Total } \\
\hline & & Home M & Branded & \\
\hline 1. & 20 - 30 years & $4(4.53)$ & $30(29.47)$ & 34 \\
\hline 2. & 30 - 40 years & $5(4.93)$ & $32(32.07)$ & 37 \\
\hline 3. & 40 - 50 years & $10(8.00)$ & $50(52.00)$ & 60 \\
\hline 4. & A bove 50 years & $1(2.53)$ & $18(16.47)$ & 19 \\
\hline & Total & 20 & 130 & 150 \\
\hline
\end{tabular}

Source: Primary Data (F igures given in the brackets represent the Expected F requency) 
Table 12: Type of Family and U se of H omemade / Branded Powder for Wheat Flour

\begin{tabular}{|c|c|c|c|c|}
\hline SI. No. & Type of F amily & Branded (b) & N on-Branded (b) & Total \\
\hline 1. & Joint $(A)$ & $8----$ & $8-----$ & 16 \\
\hline 2. & $\mathrm{~N}$ uclear (a) & 49 & $\overline{85}$ & 134 \\
\hline & Total & 57 & 93 & 150 \\
\hline
\end{tabular}

Source: Primary Data

Table 13: Type of Family and U se of Branded / N on-Branded C hilly Powder

\begin{tabular}{|c|c|c|c|}
\hline SI. No. Type of Family & Branded (B) & Non-B randed (b) & Total \\
\hline 1. $\quad$ Joint $(A)$ & 1 & 15 & 16 \\
\hline Nuclear $(\mathrm{a})$ & 31 & 103 & 134 \\
\hline Total & 32 & 118 & 150 \\
\hline
\end{tabular}

Source: Primary Data

Table 14: Type of Family and U se of Branded / N on-Branded Bengal G ram Flour

\begin{tabular}{|c|c|c|c|c|}
\hline SI. No. & Type of Family & Branded (B) & N on-Branded (b) & Total \\
\hline 1. & Joint $(A)$ & 14 & $2----$ & 16 \\
\hline 2. & N uclear (a) & 116 & 18 & 134 \\
\hline & Total & 130 & 20 & 150 \\
\hline
\end{tabular}

Source: Primary Data

Table 15: R anking Of Reasons for Switch O ver Of Brands

\begin{tabular}{|c|c|c|c|c|c|c|c|c|}
\hline SI. N 0. & Reasons & $\begin{array}{l}\mathrm{Nu} \\
\mathrm{As} \\
\mathrm{I}\end{array}$ & II & IIII & IV & $\begin{array}{l}\text { Weighted } \\
\text { Score }\end{array}$ & $\begin{array}{l}\text { Weighted } \\
\text { A verage } \\
\text { Score }\end{array}$ & R ank \\
\hline 1. & $\begin{array}{l}\mathrm{N} \text { on-A vailability of } \\
\text { Previous Brand }\end{array}$ & 7 & 8 & 7 & 22 & 88 & 2.00 & IV \\
\hline 2. & Better Q uality & 24 & 10 & 9 & 1 & 145 & 3.29 & I \\
\hline 3. & Small Packs & 1 & 21 & 5 & 7 & 104 & 2.36 & II \\
\hline 4. & Better Price & 12 & 5 & 13 & 14 & 103 & 2.34 & III \\
\hline
\end{tabular}

Source: Primary Data

Table 16: Factors G uiding the Purchase of G roceries

\begin{tabular}{|c|c|c|c|c|c|}
\hline SI. No. & Factors & $\frac{\text { Mean }}{\text { H ouse Wife }}$ & Employed & T-value & t-significance (2-tailed) \\
\hline 1. & Discounts & 1.83 & 2.38 & $4.024 *$ & 0.000 \\
\hline 2. & Free G ifts & 1.69 & 2.00 & $2.168 *$ & 0.032 \\
\hline 3. & A ttractive Packing & 2.40 & 2.55 & 1.064 & 0.289 \\
\hline 4. & Duration of Shelf Life & 2.56 & 2.95 & $3.580 *$ & 0.000 \\
\hline
\end{tabular}




\begin{tabular}{|c|c|c|c|c|c|}
\hline 5. & Small Packs & 2.59 & 2.86 & $2.300^{*}$ & 0.023 \\
\hline 6. & Low Price & 2.69 & 2.67 & 0.252 & 0.801 \\
\hline 7. & Q uality of Goods & 2.89 & 2.90 & 0.225 & 0.822 \\
\hline
\end{tabular}

* Significant at 0.05 level of significance

Table 17: 0 ccupation and Pattern of Purchase

\begin{tabular}{|c|c|c|c|c|}
\hline SI. No. & Occupation & Bulk. & Small & Total \\
\hline 1. & H ousewife & 86 (82.08) & $22(25.92)$ & 108 \\
\hline 2. & Employed & 28 (31.92) & $14(10.08)$ & 42 \\
\hline & Total & 114 & 36 & 150 \\
\hline
\end{tabular}

Source: Primary Data (Figures given in the brackets represent the Expected Frequency)

Table 18: Monthly Income And Pattern Of Purchase

\begin{tabular}{|c|c|c|c|c|}
\hline SI. N o.| & Monthly Income & Bulk & Small & Total \\
\hline$\overline{1}$. & Below Rs.10,000 & $65(66.12)$ & $22(20.88)$ & 87 \\
\hline 2. & Rs. 10,000 - Rs. 20,000 & $29(31.16)$ & $12(9.84)$ & 41 \\
\hline 3. & Rs.20,000 - Rs.30,000 & $5(4.56)$ & $1(1.44)$ & 6 \\
\hline 4. & A bove Rs.30,000 & 15 (12.16) & $1(3.84)$ & 16 \\
\hline & Total & 114 & 36 & 150 \\
\hline
\end{tabular}

Source: Primary Data (F igures given in the brackets represent the Expected Frequency)

Table 19: Reasons for Purchase in Small Lots

\begin{tabular}{|c|c|c|c|c|c|c|c|c|}
\hline \multirow[t]{2}{*}{ SI. No. } & \multirow[t]{2}{*}{ Reasons } & \multicolumn{4}{|c|}{$\begin{array}{l}\text { N umber of R espondents } \\
\text { Assigning the R anks }\end{array}$} & \multirow[t]{2}{*}{$\begin{array}{l}\text { Weighted } \\
\text { Score }\end{array}$} & \multirow{2}{*}{$\begin{array}{l}\text { Weighted } \\
\text { A verage } \\
\text { Score }\end{array}$} & \multirow[t]{2}{*}{ R ank } \\
\hline & & I & II & III & IV & & & \\
\hline 1. & Convenience & 19 & 7 & 4 & 6 & 111 & 3.08 & I \\
\hline 2. & Control O ver Consumption & 0 & 12 & 12 & 12 & 72 & 2.00 & III \\
\hline 3. & Economical & 14 & 10 & 12 & 0 & 110 & 3.06 & II \\
\hline 4. & Easy to D etermine Q uantity & 3 & 7 & 8 & 18 & 67 & 1.86 & IV \\
\hline
\end{tabular}

Source: Primary Data

Table 20: R anking of Reasons for Purchase in Bulk

\begin{tabular}{|c|c|c|c|c|c|c|c|c|}
\hline \multirow[t]{2}{*}{ SI. No. } & \multirow[t]{2}{*}{ Reasons } & \multicolumn{4}{|c|}{$\begin{array}{l}\text { N umber of R espondents } \\
\text { A ssigning the R anks }\end{array}$} & \multirow[t]{2}{*}{$\begin{array}{l}\text { Weighted } \\
\text { Score }\end{array}$} & \multirow{2}{*}{$\begin{array}{l}\text { Weighted } \\
\text { A verage } \\
\text { Score }\end{array}$} & \multirow[t]{2}{*}{ R ank } \\
\hline & & I & II & III & IV & & & \\
\hline 1. & Economic & 64 & 15 & 16 & 19 & 352 & 3.088 & I \\
\hline 2. & Door D elivery is Possible & 13 & 55 & 28 & 18 & 291 & 2.553 & III \\
\hline 3. & Convenience & 27 & 36 & 48 & 3 & 315 & 2.763 & II \\
\hline 4. & Control O ver Q uantity & 10 & 8 & 22 & 74 & 184 & 1.596 & IV \\
\hline
\end{tabular}

Source: Primary Data 
Table 21: 0 ccupation of the Respondents and Persons involved in Purchasing

\begin{tabular}{|c|c|c|c|c|}
\hline SI. No. & 0 ccupation & Self Purchase & Purchase by Somebody & Total \\
\hline 1. & H ousewife & $67(69.12)$ & $41(38.88)$ & 108 \\
\hline \multirow[t]{2}{*}{2.} & Employed & $29(26.88)$ & $13(15.12)$ & 42 \\
\hline & Total & 96 & 54 & 150 \\
\hline
\end{tabular}

Source: Primary Data (Figures given in the brackets represent the Expected F requency)

Table 22: Education and A wareness of C onsumer Rights

\begin{tabular}{|c|c|c|c|c|}
\hline SI. No. & Education & A ware & Not Aware & Total \\
\hline 1. & Secondary E ducation & $18(34.44)$ & $\underline{45} \underline{(28.56)}$ & 63 \\
\hline 2. - & H igher Secondary Education & $20(20.77)$ & $18 \underline{(17.23)}$ & 38 \\
\hline 3. & College Education & $44(26.79)$ & $5(22.21)$ & 49 \\
\hline & Total & 82 & 68 & 150 \\
\hline
\end{tabular}

Source: Primary D ata (Figures given in the brackets represent the Expected F requency) 